\title{
KESKUSTELUJA
}

\section{Ikääntyneiden naapurisuhteista ja -verkostoista}

\author{
Hanna Varjakoski
}

\section{Johdanto}

Sosiaalisten kontaktien on esitetty olevan tärkein asia iäkkäiden ihmisten hyvinvoinnin kannalta (von Faber ym. 2001). Läheisten ihmissuhteiden ja inhimillisen vuorovaikutuksen on nähty edesauttavan hyvää ikääntymistä, etenkin mitä vanhemmista ikäryhmistä on kyse (esim. Litwin \& Shiovitz-Ezra 2006). Ikäihmisten sosiaalisia suhteita koskevassa tutkimuksessa on kuitenkin pitkälti keskitytty tarkastelemaan perhesiteisiin perustuvia verkostoja. Tähän on otaksutusti vaikuttanut se, että vallitsevan kulttuurisen olettamuksen mukaan perhe nähdään iäkkäiden ihmisten ensisijaisena sosiaalisena viiteryhmänä ja tuen lähteenä (mm. Barker 2002). Perheen sisäiset konfliktit tai perinteisen perherakenteen puuttuminen ympäriltä (esim. Boggs ym. 2017; Deindl \& Brandt 2017) voivat kuitenkin estää tukeutumisen perheen tukeen. Perhe ei myöskään välttämättä ole se yhteisö, jonka kanssa ollaan päivittäin ja eniten tekemisissä. Ystävien ja tuttavien ohella naapurit voivatkin olla ikääntyneen arjessa perhettä jopa keskeisempi yhteisö (Jolanki ym. 2017).

Artikkeli luo katsauksen vanhempien ihmisten naapurisuhteita ja -verkostoja käsittelevään kotimaiseen ja kansainväliseen tutkimukseen. Tavoitteena on muodostaa yleiskuva ikääntyneiden naapurisuhteista ja selvittää naapureiden merkitystä osana vanhempien ihmisten sosiaalisia verkostoja. ${ }^{1}$ Kirjoituksessa tarkastellaan erityisesti naapuriapua, sillä informaalien tukiverkostojen ja naapuriavun on joissain tilanteissa todettu edesauttavan ikäihmisen asu- mista omassa kodissa. Naapuruston voi täten katsoa toimivan voimavarana, joka parhaimmillaan tukee ikääntyneen elämänlaatua ja arjessa selviytymistä. Naapuriavun kannalta on tärkeää tunnistaa avun saamista ja antamista vahvistavia ja heikentäviä tekijöitä, jotta mahdollisia hyvinvointihyötyjä tuottavia naapurisuhteita voitaisiin edistää. Tärkeää on myös tuoda enemmän esille vanhempien ihmisten aktiivista roolia naapuriavun antajina, jotta he eivät näyttäytyisi yksipuolisesti vain apua tarvitsevana ja saavana osapuolena.

Kirjoitus lähtee liikkeelle aihetta taustoittavalla osuudella, jossa luodaan yleisluontoinen silmäys ikääntyneiden ihmisten sosiaalisiin suhteisiin ja siihen liittyvään tutkimukseen. Ennen varsinaista naapuriapua käsittelevää osiota aihetta pohjustetaan selvittämällä muun muassa, kenen kanssa ikääntyneet ovat eniten tekemisissä naapurustossaan ja missä naapurisuhteita tavallisimmin luodaan ja ylläpidetään. Katsauksen päättää pohdinta vanhempiin ihmisiin liittyvien kulttuuristen käsitysten roolista naapurisuhteiden muokkaajina.

\section{Ikääntyneiden sosiaaliset suhteet}

Ennusteiden mukaan vuonna 2030 joka neljäs suomalainen on yli 65-vuotias. Yhä useampi heistä asuu kaupungissa ja kerrostalossa. Tällä hetkellä esimerkiksi 75-vuotiaista ja sitä vanhemmista ihmisistä yli 40 prosenttia asuu tavanomaisissa kerrostaloasunnoissa ja lähes puolet tämän ikäryhmän kerrostaloasujista asuu yksin (SVT 2019; Tilastokeskus 2019). 
Samalla kun väestörakenteen vanhenemisen myötä tukea ja apua tarvitsevien ikääntyneiden määrä lisääntyy, myös iäkkäille sopivien asumisratkaisujen tarve kasvaa. Kysymyksiin fyysisestä asuinympäristöstä, turvallisesta asumisesta ja paikoillaan vanhenemisesta omassa kodissa onkin kohdistunut viime aikoina runsaasti tutkimusintressiä. Vähemmälle huomiolle ovat kuitenkin jääneet asumisen sosiaaliseen kontekstiin liittyvät kysymykset, erityisesti ikääntyneiden naapurisuhteet ja -verkostot, vaikka asuinalueelle kiinnittyvien sosiaalisten suhteiden merkityksen on todettu olevan ikääntyneille muita ikäryhmiä suurempi (Seppänen ym. 2012).

Naapuruussuhteita käsittelevän tutkimuksen valossa naapureilla näyttäisikin olevan merkittävä asema ikääntyneiden ihmisten sosiaalisissa verkostoissa. Koska vanhemmat ihmiset ovat usein asuneet tietyssä paikassa pidempään, naapureiden välille on saattanut kehittyä vahvojakin tunnesiteitä, jolloin pinnalliseksi ja instrumentaaliseksi luonnehdittu naapurisuhde on muovautunut läheiseksi ystävyyssuhteeksi (Wenger 1990). Ikääntyneiden ystävä- ja naapurisuhteita koskevassa tutkimuksessa on havaittavissa tiettyä samankaltaisuutta, mikä johtunee juuri ystävien ja naapureiden välisen rajan epäselvyydestä ja päällekkäisyydestä pitkäaikaisissa naapurisuhteissa.

Iän karttuessa naapuri- ja ystäyyyssuhteiden on sanottu vähenevän samalla kun suhteet virallisiin tahoihin lisääntyvät. "Vanhoista vanhimpien" ihmisten sosiaalisesta elämästä ei kuitenkaan tiedetä yhtä paljon kuin nuorempien ikäryhmien. Joitakin poikkeuksia toki löytyy. Iäkkäiden ihmisten näkökulmia suomalaisessa kontekstissa ovat viime aikoina kartoittaneet ainakin Tuominen ja Pirhonen (2019), jotka ovat selvittäneet yli 90-vuotiaiden sosiaalisia verkostoja ja heidän läheisille suhteille antamiaan merkityksiä. Kyseinen tutkimus tuo hyvin esille ihmissuhteisiin liittyviä ominaisuuksia ja haasteita, jotka ovat erityisiä myöhäisvanhuutta eläville ihmisille. Ominaista tälle ikäryhmälle on esimerkiksi se, että monilla ei ole ikätovereita ja ystäviä enää elossa, mikä luonnollisesti kutistaa heidän sosiaalista piiriään. Vanhoista vanhimpien ihmisten sosiaaliselle elämälle on Tuomisen ja Pirhosen mukaan tyypillistä myös asuinpaikkaan sidottu sosiaalisuus (place-bound sociality). Oma koti toimii siinä keskeisenä areenana, jonne tullaan kyläilemään ja josta käsin ylläpidetään ihmissuhteita. Sosiaalisen elämän keskittyessä pitkälti kotiin naapureidenkin merkitys kasvaa. Lähellä olevat naapurit tarjoavat ikäihmisille sekä seuraa että apua: arjen askareissa autetaan puolin ja toisin, mutta naapureiden kanssa vietetään aikaa myös kahvitellen, jutustellen ja ulkoillen. (Tuominen \& Pirhonen 2019).

Terveyden heikentyminen asettaa omat rajoitteensa sille, missä määrin vanhemmilla ihmisillä on mahdollisuuksia osallistua kodin ulkopuoliseen toimintaan, ylläpitää olemassa olevia ihmissuhteita ja solmia uusia (ks. Wenger 1990; Tuominen \& Pirhonen 2019). Sosiaalisten kontaktien määrä vähenee, kun kodin ulkopuolelle ei esimerkiksi haluta tai voida enä lähteä liikuntakykyyn ja muihin liittyvien haasteiden lisääntyessä (ks. Vuorimies 2012). Sosiaalisten suhteiden merkitys ei kuitenkaan katoa minnekään, vaikka mahdollisuudet tavata muita ihmisiä vähenevät: suhteet läheisiin ja ystäviin ovat tärkeä osa iäkkäiden ihmisten elämää ja hyvinvointia. Vanhuutta ja yksinäisyyttä tutkineen Uotilan (2011) mukaan sosiaalisten kontaktien määrä tärkeämmäksi nouseekin olemassa olevien suhteiden laatu ja tyytyväisyys niihin.

\section{Ikääntyneiden naapuriverkostot ja -suhteet}

Suomalaisia naapuruuden piirteitä tutkineen Hirvosen (2013) mukaan suurkaupunkien alueella naapuruudella on melko rajallinen rooli ja ihmisille tärkeät verkostot löytyvät muualta kuin naapurustosta. Vanhemmat ikäryhmät muodostavat tästä kuitenkin poikkeuksen. Yli 65-vuotiailla on eniten ystäviä ja tärkeitä ihmisiä naapurustossa, ja he myös juttelevat naapu- 
reiden kanssa nuoria ikäluokkia selvästi useammin ja omaavat laajimman jutteluverkoston asuinalueellaan.

Tutkimus on osoittanut, että ikääntyneet ovat eniten tekemisissä samanikäisten naapureiden kanssa. Eläkkeellä olevat ihmiset ovat usein paikalla päiväsaikaan, mikä edesauttaa naapurikohtaamisia samaa elämänvaihetta elävien kanssa. Kontaktit nuorempien naapureiden kanssa voivat vastaavasti jäädä vähäisiksi nopean asukasvaihtuvuuden, erilaisen päivärytmin ja nuorten kiireisen elämäntyylin vuoksi. (Wenger 1990.) Monisukupolvista yhteisöllistä asumista kotimaan kontekstissa tarkastelleen Erosen (2019) mukaan ikäpolvien eroavaisuudet juuri ajankäytössä sekä hakeutuminen asuintalojen yhteisissä tiloissa eri areenoille hankaloittavat eri-ikäisten naapureiden kohtaamista ja sukupolvien välisten suhteiden luomista.

Suhteiden kehittymistä nuorempien naapureiden kanssa saattavat haitata myös kokemukset siitä, ettei heidän kanssaan ole mitään yhteistä (Ziegler 2012), puhumattakaan mahdollisista ennakkoluuloista ja -asenteista muun ikäisiä kohtaan."Ikäpolviolentoina" saatamme kokea, että on helpompi ymmärtää omanikäisten ihmisten intressejä, ajattelua ja toimintatapoja kuin itseä nuorempien tai vanhempien (Saarenheimo 2013). Myös iän itsessään voidaan nähdä aiheuttavan kuilua eri-ikäisten naapureiden välille. Jotkut ikääntyneet saattavat vähentää kontaktien ottamista nuorempiin ihmisiin, jos he kokevat nuorempien vierastavan iäkkäitä naapureita näiden korkean iän vuoksi (ks. Palkeinen 2007).

Naapureiden läheisyys ja kontaktit muiden asukkaiden kanssa luovat vanhemmille ihmisille turvallisuuden ja kuuluvuuden tunnetta (ks. Dunér \& Nordström 2007; Eronen 2019). Lähinaapurit ovat keskeisessä roolissa ikääntyvän naapuriverkostossa, mutta omaan naapuriverkostoon saatetaan laskea kuuluvaksi myös lähikauppojen tutut myyjät ja paikallisen pankin tai postin henkilökuntaa (Gardner 2011). Varsinkin yksinasuville ikääntyneille sosiaaliset kontaktit naapureihin voivat olla erityisen tärkeitä. Arkiset kohtaamiset ja jutustelu naapurin kanssa tapahtuvat usein spontaanisti mutta saattavat silti olla ikääntyneelle merkittäviä tapahtumia. Tätä tukee myös hollantilaisia ikääntyneitä haastatelleiden Lagerin ja kumppaneiden (2015) tutkimus, jonka mukaan haastateltavat pitivät suuressa arvossa "tuttujen naamojen" näkemistä ja naapureiden kanssa jutustelua eli löyhiä naapurisuhteita, joihin ei liittynyt odotuksia tai velvoitteita.

Ulkomaisissa tutkimuksissa ikääntyneet kuvailevat suhteitaan naapureihin yleensä positiivisessa valossa ja suhteet nähdään vastavuoroisina ja molemminpuoliseen tukeen pohjautuvina (esim. Gardner 2011). Myös suomalaisessa tutkimuksessa ikääntyneiden naapurisuhteet näyttäytyvät myönteisinä. Perhesuhteista ja naapureista ollaan kiitollisia ja hyvien ihmissuhteiden koetaan tuovan iloa, turvaa, apua arjen askareisiin sekä liennyttävän yksinäisyyttä (Kariniemi ym. 2020). Hirvosen (2013) naapuruuskyselyn tulokset osoittavat, että mitä iäkkäämmästä vastaajasta oli kyse, sitä useammin hän piti naapurustoaan sopuisana, puuttui epätodennäköisemmin naapuriongelmiin ja oli kaikin puolin mukautuvampi naapurihäiriöihin. Samansuuntaisia tuloksia ovat tuoneet esille myös Kouvo ja Haverinen (2017) naapurikiistoja koskevassa tutkimuksessaan.

\section{Rakennetun ympäristön merkitys}

Fyysisellä asuinympäristöllä voi olla merkittävä rooli naapurikontaktien mahdollistajana. Puistot, penkit, ruokakaupat, kävelykadut sekä läpikulkuun tarkoitetut tilat (kerrostalojen aulat, pankkien ja kauppojen jonot sekä bussipysäkit) ovat vanhemmille ihmisille tärkeitä sosiaalisia paikkoja, joissa naapurisuhteita rakennetaan ja ylläpidetään. Naapurikontaktien kannalta tärkeitä paikkoja ovat myös takapihat, parvekkeet ja patiot, joilta on helppo tervehtiä naapureita ja vaihtaa kuulumisia. (Gardner 2011.) 
Ympäristö voi toisaalta asettaa haasteita tutustumiselle ja tapaamiselle naapuruston muiden asukkaiden kanssa. Ikääntyneille merkittävien kohtaamispaikkojen, kuten lähikauppojen ja postien, katoaminen sekä pitkät välimatkat ja julkisen liikenteen supistuminen vaikeuttavat naapureiden kohtaamista etenkin maaseudulla (ks. Vuorinen 2009). Urbaanimmasta ympäristöstä taas on väitetty, että kaupunkien yhteiset tilat nähdään monesti työikäisten aikuisten alueiksi, joissa "liian vanhat" saattavat kokea olevansa väärässä paikassa (Saarenheimo 2013). Sopivaksi koetun kohtaamis- ja ajanviettopaikan löytäminen oman kodin välittömästä läheisyydestäkin voi osoittautua ongelmalliseksi. Esimerkiksi kerrostalojen yhteiseen oleskeluun tarkoitetuissa tiloissa (mikäli niitä edes on) tapahtuva vapaamuotoinen oleskelu hyvin eri-ikäisten naapureiden kanssa saatetaan kokea hankalaksi (ks. Saarenheimo 2013), mikä voi johtaa yhteisten tilojen välttelyyn tai vuorovaikutukseen ainoastaan samaan ikäryhmään kuuluvien kanssa.

Aikaisempi tutkimus on lisäksi osoittanut, että iäkkäät ihmiset poistuvat kodeistaan epätodennäköisemmin, jos he kokevat naapurustonsa turvattomaksi tai jos asuinympäristöä ei koeta "ikäystävälliseksi" liikkumisen kannalta (aiheesta laajemmin, esim. Cramm \& Nieboer 2014; Day 2008). Eristäytyminen omaan kotiin hankaloittaa suhteiden ylläpitoa naapuruston muiden asukkaiden kanssa, vaikka yhteydenpito itselle merkityksellisiin ihmisiin puhelimen ja sosiaalisen median välityksellä voi osaltaan kompensoida liikkumiseen ja tapaamismahdollisuuksiin liittyviä haasteita.

\section{Ikääntyneet ja naapuriapu}

Naapureiden merkitys ikääntyneiden hyvinvoinnille ja itsenäiselle asumiselle on nähty niin suureksi, että erityisiä naapuruusohjelmia (esim. Trickey ym. 2008; Greenfield 2016), yhteisöllisen asumisen muotoja (mm. Jolanki \& Vilkko 2015; Eronen 2019) ja sosiaalisen me- dian sovelluksia (ks. www.nappinaapuri.fi/) on kehitetty edistämään naapureiden kohtaamista ja naapuriapuun osallistumista.

Lukuisat kansainväliset tutkimukset osoittavat, että naapurit ovat merkittävä tuen lähde vanhemmille ihmisille, etenkin lapsettomille ikääntyneille (esim. Nocon \& Pearson 2000; Barker 2002; Shaw 2005; Albertini \& Kohli 2009; Deindl \& Brandt 2017). Tutkittua tietoa Suomen kontekstissa löytyy hajanaisesti. Aihetta sivutaan muun muassa paikallaan vanhenemisen (esim. Vasara 2020), yhteisöllisen asumisen ja yhteisöllisyyden (esim. Jaakkola 2015; Jolanki ym. 2017), sosiaalisen osallisuuden (esim. Nurmela 2012), ikäihmisten mielen hyvinvoinnin (Kuisma 2017), lähiötutkimuksen (Seppänen ym. 2012) ja sosiaaligerontologisen kylätutkimuksen (Vuorinen 2009) yhteydessä. Myös Hirvosen (2013) suomalaisen naapuruuden piirteitä tarkastelevasta tutkimuksesta löytyy määrällistä tietoa vanhempien ikäryhmien osallistumisesta naapuriapuun. Vuonna 2012 kerätyn aineiston mukaan naapuriapuun osallistui auttavana tai saavana osapuolena viikoittain 13 prosenttia ja kuukausittain 30 prosenttia vastaajista. Kaikkein aktiivisimpia olivat 60-64-vuotiaat, mutta myös sitä vanhemmat ihmiset auttoivat naapureitaan nuoria ikäryhmiä selkeästi enemmän. ${ }^{2}$

Kotimaisessa ikääntymistä tarkastelevassa tutkimuksessa on todettu rappukäytävänaapureiden tarjoavan toisilleen tärkeän sosiaalisen ja epävirallisen avun verkoston (Vasara 2016). Naapuriavun saaminen on nähty myös yhtenä keskeisenä reunaehtona ikääntyneen asumiselle omassa kodissa mahdollisimman pitkään, etenkin syrjäkylillä (ks. Jaakkola 2015). Naapuruussuhteiden nähdään edustavan enimmäkseen niin sanottuja heikkoja siteitä, mutta säännöllinen naapuriapu edustaa jo askelta syvemmän tuttavuuden suuntaan (Hirvonen 2013). Naapuruuden kehittymistä hyvänpäiväntuttuudesta kohti avunannon muotoja sisältävää naapurisuhdetta näyttäisi kirjallisuuskatsauksen valossa edesauttavan ainakin asuinpaikassa luotu tiivis sosiaalinen verkosto ja va- 
kiintuneempi asuminen samalla alueella. Pidempään tietyssä paikassa asuneilla ikääntyneillä onkin naapurustossa tavallisesti vakiintuneita sosiaalisia suhteita, joihin voi tarvittaessa tukeutua olosuhteiden muuttuessa. Avun saajat ovat usein tunteneet naapurinsa jo pitkään ennen naapuriavun alkamista (Grime 2018). Avun ja tuen tarpeen lisääntyessä ikääntyneiden sosiaalisilla verkostoilla on mahdollisuuksia kehittyä tukiverkostoiksi ja siitä edelleen jopa hoivan antamisen verkostoiksi (Barker 2002; Keating ym. 2003). Muuttaminen myöhemmällä iällä uuteen asuinpaikkaan, jolloin tutut naapurit ja asuinyhteisö jäävät taakse, voi vastaavasti johtaa tukea tarjoavan naapuriverkoston menettämiseen (ks. Kangassalo \& Teeri 2017).

\section{Naapuriavun muodot}

Naapuriapu on usein konkreettista apua, esimerkiksi kyydin tarjoamista, eläinten hoitoa, kukkien kastelemista ja lumitöiden tekoa, tai rahaa vastaan tehtäviä työsuorituksia, kuten tien auraamista, peltojen kyntämistä ja puiden kaatamista (Vuorinen 2009). Tavallisimmin naapuriavussa on kuitenkin kyse pienten palvelusten tekemisestä ja arkisissa askareissa avustamisesta - oli kyse sitten maaseutu- tai kaupunkiympäristössä asuvista ikääntyneistä.

Käytännön avun lisäksi emotionaalinen tuki, kuten juttuseuran ja lohduttavan olkapään tarjoaminen, mainitaan tutkimuskirjallisuudessa yhtenä merkittävänä naapuriavun muotona. Tämänkaltainen tuki on yhtä lailla arvokasta, sillä sen on katsottu liennyttävän niin yksinäisyyttä, ahdistusta kuin turvattomuuden tunnettakin. On jopa esitetty, että naapureiden ja ystävien merkitys henkisen tuen ja avun antajina ylittäisi konkreettisen avun merkityksen. Tukea antavien naapureiden puuttuminen taas voi nostattaa tuntemuksia yhteisön ulkopuolelle joutumisesta ja eristyneisyydestä. (Jaakkola 2015.)

Perheen ja ystävien antamaan tukeen verrattuna naapureiden maantieteellinen lähei- syys mahdollistaa monien välittömien, pienempien avuntarpeiden täyttämisen ja naapureiden molemminpuolisen"perään katsomisen". Huomatut poikkeukset arkirutiineista, suljetut verhot ikkunassa tai hoitamaton piha saattavat kertoa siitä, että naapurissa asiat eivät ole kunnossa. Tämänkaltainen sosiaalinen monitorointi yhdessä instrumentaalisen avun ja henkisen tuen kanssa ovatkin yleisimmät naapurituen muodot (van Dijk ym. 2013).

Naapureilta saadaan apua etenkin hätätilanteissa, mutta pitkäaikaisen avun ja tuen antamiseen naapurit eivät tutkimusten mukaan ole kovin innokkaita sitoutumaan (Wenger ym. 2007). Naapurit auttavat määrällisesti ja ajallisesti vähemmän kuin ystävät, minkä Lapierre ja Keating (2013) tulkitsevat johtuvan naapurisuhteita säätelevistä käsityksistä, joihin kuuluu tietyn etäisyyden pitäminen ja toisen yksityisyyden kunnioittaminen. Kuitenkin jo pelkkä tietoisuus siitä, että lähellä on ihmisiä ja että naapuriapua on saatavilla sitä tarvittaessa, tuottaa ikääntyneille turvallisuudentunnetta ja rohkaisee toimimaan itsenäisesti (Shaw 2005).

Naapureiden auttaminen tapahtuu useimmiten luontaisesti ja on osa "hyvää naapuriutta". Pienissä ja satunnaisissa arjen tarpeissa avustaminen alkaa useimmiten ikään kuin vaivihkaa ikääntyvän naapurin kunnon huonontuessa, laajeten toisinaan jopa päivittäiseksi avustamiseksi. Avunanto muovautuu siis olosuhteiden mukana (Grime 2018). Joissakin tapauksissa ikääntynyttä naapuria auttava saattaa itsekin olla jo melko iäkäs ja raihnainen. Tämänkaltaisissa tilanteissa naapurin tukeminen saattaa kuormittaa avun antajaa. Van Dijkin ja kumppaneiden (2013) mukaan vaarana on jopa naapuriavun muotoutuminen taakaksi, jos avunannosta ei hennota luopua, koska koetaan moraalista velvoitetta auttaa heikommassa asemassa olevaa.

Lähinaapureilta saatu apu on usein nopeaa ja joustavaa, eikä sitä ole sidottu tiettyihin kellonaikoihin, kuten julkisista lähteistä saatu tuki on (Nocon \& Pearson 2000). Naapuriavun on huomattu eroavan muilta saadusta tuesta siinä, 
että naapurit tavallisesti auttavat kodin ja pihan hoitoon liittyvissä askareissa, kun taas perhe ja ystävät auttavat enemmän henkilökohtaisissa ja intiimeissä avuntarpeissa. Naapuriudella näyttäisikin olevan selvät rajat, kun kyse on intensiivisemmästä tuen tai hoivan tarpeesta. Vaikka toisten auttaminen koetaan tärkeänä, kontakteja paljon apua tarvitseviin ikääntyneisiin naapureihin saatetaan rajoittaa, koska ei haluta ryhtyä hoivan antajiksi vaan pysyä pikemminkin ystävinä (ks. Lapierre \& Keating 2013; Hand ym. 2018). Mitä myöhäisemmästä vanhuudesta on kyse, sitä enemmän tukiverkoston painopiste siirtyy perheen suuntaan ja muista informaaleista lähteistä saatu apu vähenee (Wenger ym. 2007).

\section{Avun pyytäminen ja vastavuoroisuus}

Aikaisemman tutkimuksen perusteella vanhemmat ihmiset sekä saavat että antavat naapuriapua. Naapuriapuun liitetään vahvasti ajatus vastavuoroisuudesta. Vastavuoroisuus voidaan kokea jopa vaateena, jolloin avun vastaanottaja kokee vastapalveluksen tekemisen välttämättömäksi (Vuorinen 2009). Mikäli vastavuoroisuutta ei kyetä omalta osalta jostain syystä täyttämään, kynnys pyytää apua kasvaa. Tämä saattaa muotoutua ongelmalliseksi etenkin hyvin iäkkäiden tai terveysongelmien kanssa kamppailevien ikääntyvien kohdalla.

Arviointia siitä, missä menee liiallisen avun antamisen ja pyytämisen raja, tehdään puolin ja toisin: tasapainossa olevaa naapurisuhdetta pidetään tärkeänä. Naapureille ei haluta olla taakkana eikä ystävällisyyteen perustuvan naapuriuden rajaa mielellään venytetä liiaksi (ks. Nocon \& Pearson 2000). Avun pyytämiseen naapureilta liittyy tiettyä vastahakoisuutta (ks. Grime 2018). Avuntarve saatetaan tulkita heikkoudeksi, mikä voi erityisesti ikääntyneille miehille tuottaa häpeää, kuten sukupuolisensitiivisessä ikääntymisen tutkimuksessa on tullut esille (Pietilä 2013).
Vastahakoisuus pyytää apua liittynee myös laajempaan kulttuuriseen ajattelumalliin, joka ihannoi riippumattomuutta ja pärjäämistä (ks. Schwanen ym. 2012). Kotimaan kontekstissa suomalaisten perinteistä pidättyväisyyttä ja keskittymistä omista asioista huolehtimiseen ei myöskään sovi aliarvioida avun pyytämistä ja auttamisintoa hillitsevinä tekijöinä. Onhan näiden edellä mainittujen piirteiden arveltu haittaavan laajemminkin ikäpolvien kohtaamista perheiden ulkopuolella (ks. Saarenheimo 2013).

Avunsaajille on merkityksellistä, että naapurit auttavat, koska haluavat auttaa, eivätkä siksi, että heille maksetaan siitä tai että he kokevat velvollisuudekseen auttaa (Nocon \& Pearson 2000). Vanhempien ihmisten on lisäksi todettu olevan valikoivampia sen suhteen, milloin ja keneltä apua pyydetään sekä millaista apua toivotaan (Seifert \& König 2019). Erään tutkimuksen mukaan ikääntyneet esimerkiksi ottavat mieluummin apua vastaan puolisolta kuin jälkeläisiltä, sukulaisilta, ystäviltä tai naapureilta (Keating ym. 2003). Kaiken kaikkiaan, avun vastaanottamiseen ja pyytämiseen näyttäisivät vaikuttavan lukuisat eri tekijät, kuten avun muoto, suhteen läheisyys, kenen nähdään olevan soveltuva avun antamiseen, voidaanko saatu apu korvata ja kuinka ylipäätään ympäröivässä kulttuurissa suhtaudutaan ajatukseen ihmisistä muista riippuvaisina ja apua tarvitsevina olentoina.

\section{Yhteenvetoa ja loppupohdintaa}

Naapurit ovat tehdyn katsauksen perusteella tärkeä osa ikääntyneiden ihmisten sosiaalista elämää, sosiaalisia verkostoja ja tukiverkostoja. Vanhempien ihmisten naapurisuhteista ja muista vapaamuotoisista sosiaalisista suhteista kuitenkin tiedetään melko vähän - varsinkin jos ulkopuolelle jätetään näiden suhteiden instrumentaalisia ulottuvuuksia korostavat tarkastelut. 
Naapureiden merkitys näyttäisi vahvistuvan etenkin tilanteissa, joissa perheenjäsenet ja sukulaiset asuvat kaukana tai heitä ei ole. Sama koskee satunnaisia tuen tarpeita ja hätätilanteita, jolloin naapureiden läheisyys ja avun nopea saatavuus korostuvat. Naapuriavun saamista ja antamista edesauttaa merkittävästi vakiintunut asuminen tietyssä paikassa, jolloin naapurit ovat ajan saatossa tulleet tutuiksi ja naapurisuhde on voinut syventyä jopa ystävyydeksi asti. Tietyssä paikassa pidempään asuminen ei tosin automaattisesti tarkoita, että ikääntyneellä olisi tiivis sosiaalinen verkosto naapurustossaan. Haluttomuus olla naapureiden kanssa tekemisissä, naapureiden poismuutot ja kuolemat sekä liikkumiseen liittyvät haasteet voivat etenkin myöhemmällä iällä merkittävästi supistaa ikääntyneiden naapuriverkostoja.

Ikääntyneet ovat eniten tekemissä omanikäisten naapureiden kanssa. Useista katsausta varten läpikäydyistä artikkeleista käy kuitenkin ilmi, että vanhemmat ihmiset toivovat enemmän kohtaamisia nuorempien naapureiden kanssa ja ovat avoimia suhteiden muodostamiselle eri-ikäisten ihmisten kanssa. Kohtaamismahdollisuuksia ja syvempiä sukupolvien välisiä suhteita näyttäisi tosin olevan hankalampi luoda. Eroavaisuudet esimerkiksi ajankäytössä esitetään yhtenä huomattavana esteenä eri ikäpolveen kuuluvien ihmisten naapurisuhteiden kehittymiselle.

Eri-ikäisten naapureiden vähäiset kontaktit tai kohtaamattomuus eivät välttämättä johdu pelkästään eri ikäryhmien eroavaisuuksista ajankäytössä ja eriaikaisesta liikkumisesta naapurustossa. Taustalla vaikuttavat monet muutkin tekijät, kuten esimerkiksi kokemukset siitä, ettei nuorempien naapureiden kanssa ole mitään yhteistä, sekä erilaiset kielteissävytteiset kulttuuriset käsitykset vanhemmista ihmisistä, mistä kulttuurigerontologia tarjoaa runsaasti tutkimusnäyttöä. Vastavuoroiseen tukeen perustuvat naapurisuhteet voivat edistää kaikenikäisten hyvinvointia ja elämänlaatua, mutta jotta tämä yhtälö todella toimisi, meidän tulee kohdata ja ylittää syvälle juurtuneita, negatii- visia käsityksiä ikääntymisestä, kuten amerikkalaisgerontologit Thomas ja Blanchard (2009) peräänkuuluttavat.

Vanhenemiseen liittyy paljon myyttejä, pelkoja ja kielteisiä stereotypioita. Väistämätön kognitiivinen rapistuminen, yksinäisyys, taloudellisena taakkana oleminen ja riippuvuus muista ihmisistä ovat kenties yleisimpiä ikääntymiseen liitettyjä käsityksiä (ks. Thornton 2002; Angus \& Reeve 2006). Etenkin nuoruutta ja keski-ikää elävien ihmisten näkemyksissä elämän jälkipuolisko saattaa näyttäytyä pelottavana ja hankalana, mistä pitkälti on kiittäminen nuorekkuutta ihannoivaa kulttuuriamme. Kulttuuriset käsitykset vanhemmista ihmisistä tapoihinsa jämähtäneinä (O’Dare ym. 2019b) tai muuten kyvyttöminä ja hyödyttöminä yhteisön jäseninä eivät nekään varsinaisesti edistä sukupolvien välisten naapurisuhteiden muotoutumista.

Yhteiskunnalliset normit ja kulttuuriset käsitykset muokkaavat sitä, miten eri-ikäiset ovat (tai miten heidän "tulisi" olla) vuorovaikutuksessa toistensa kanssa. Vanhemmat ihmiset saatetaan kulttuurisesti nähdä "epäsopivina" ystävinä nuoremmille aikuisille ja sukupolvien väliset ystävyyssuhteet leimataan helposti jopa oudoiksi (O’Dare ym. 2019a). Pahimmillaan eri-ikäisten ihmisten ystävyys- ja naapurisuhteiden syventymistä voivat haitata muiden suunnalta tulevat epäilyt suhteen vilpittömyydestä tai jopa hyväksikäytöstä - etenkin jos suhteeseen sisältyy ikäihmisen avustamista (ks. Barker \& King 2001; Barker 2002).

Ikääntymistä on tavattu tarkastella kasvavan hoivan ja tuen tarpeen näkökulmasta. Vanhempia ihmisiä lähestytään usein homogeenisena ryhmänä, vaikka erilaiset elämänkokemukset ja -polut, perimä, terveydentila ja lukuisat muut tekijät vaikuttavat siihen, että ikääntyneet ovat viime kädessä hyvin heterogeeninen ryhmä.

Ikääntyneille on nykyään tarjolla huomattavasti enemmän mahdollisuuksia ja moninaisempia sosiaalisia rooleja kuin aikaisemmilla sukupolvilla on ollut. Viimeaikaisessa tutkimuk- 
sessa vanhempia ihmisiä onkin siirrytty tarkastelemaan myös antavana ja kontribuoivana osapuolena (Vidovicová 2018). Ikääntyneiden voimavaroja on pyritty tunnistamaan ja tunnustamaan (mm. Heikkinen \& Marin 2002; Suomi \& Hakonen 2008; Topo \& Jyrkämä 2020) ja eläkeläisten aktiivista roolia sekä generatiivisuutta esimerkiksi vapaaehtoistyössä on tuotu enemmän esille (mm. Narushima 2005; Äyräväinen ym. 2019). Ylipäätään vanhempien ihmisten asemoiminen pelkästään passiivisiksi avunsaajiksi jättää huomiotta ikääntyneiden tekemän merkittävän työn yhteisöjen ja naapurustojen hyväksi (ks. Wiles \& Jayasinha 2013; Hand ym. 2018), tärkeän roolin isovanhempina, hoivan antajina ja läheisten tukijoina (ks. Fuller-Thomson ym. 1997; Kafková 2015) sekä kontribuution sosiaaliseen muutokseen tähtäävässä toiminnassa (esim. Narushima 2004; Pedersen 2010).

Vanhemmilla ihmisillä on usein elämän varrella kerrytettyjä erilaisia verkostoja ja sosiaalisia resursseja. Monella ikääntyneellä on myös halukkuutta toimia toisten ihmisten ja yhteiskunnan hyväksi. Hyödyt ovat molemminpuolisia, sillä läheisten ja naapureiden auttaminen tai globaalin hyvän puolesta toimiminen tuo hyvää mieltä, luo tarpeellisuuden tunnetta ja antaa merkityksellisyyden kokemuksia, jotka ovat ikääntyneiden elämänlaadun ja itsetunnon kannalta tärkeitä (ks. Sarvimäki 2007; Saarenheimo 2013). Toiminta naapureiden ja yhteisön hyväksi avaa myös mahdollisuuksia osoittaa, että ikääntyneet ovat edelleen aktiivisia yhteiskunnan jäseniä. Ikäihmisten taitojen, elämänkokemuksen ja hiljaisen tiedon arvostaminen ja näkyväksi tekeminen muovaa ikääntymisasenteita myönteisempään suuntaan, mikä voi osaltaan tasoittaa tietä sukupolvien välisten suhteiden muodostumiselle. Lisätutkimusta kuitenkin tarvitaan selvittämään, millaisilla eri tavoilla vanhemmat ihmiset voivat toimia naapurustonsa voimavarana ja miten vastavuoroisia naapurisuhteita voidaan edistää.

\section{Yhteydenotto:}

Hanna Varjakoski, projektitutkija, FM

Turun yliopisto

hanvarz@utu.fi

\section{Viitteet}

1 Katsaus on tehty professori Hannu Ruonavaaran johtaman Ikääntyvän kaupunkilaisen naapuriverkostot - yksinäisyyden torjuntaa ja vastavuoroista tukea? -tutkimushankkeen tueksi. Kyseessä on Turun kaupunkitutkimusohjelmaan kuuluva tutkimus, joka toteutetaan v. 20202021 Turun yliopiston Sosiaalitieteiden laitoksella, yhteistyössä Itä-Suomen yliopiston Yhteiskuntatieteiden laitoksen ja Sosiaali- ja terveysjohtamisen laitoksen kanssa. Kirjoittaja toimii hankkeessa projektitutkijana.

${ }^{2}$ Hirvosen tutkimuksessa ei tehty eroa naapuriavun antamisen ja saamisen välille vaan kysyttiin yleisesti osallistumisesta naapuriapuun. Tutkimukset ovat osoittaneet, että avun saamisessa ja antamisessa on kuitenkin vahvaa ikäsidonnaisuutta.

\section{Kirjallisuus}

Albertini M, Kohli M. What childless older people give: is the generational link broken? Ageing Soc 2009;29:1261-74. https://doi.org/10.1017/S0144686X0999033X

Angus J, Reeve P. Ageism: a threat to "aging well" in the $21^{\text {st }}$ century. J Appl Gerontol 2006;5(2):137-52. https://doi.org/10.1177\%2F0733464805285745

Barker JC. Neighbors, friends, and other nonkin caregivers of community-living dependent elders. J Gerontol B 2002;57:S158-67. https://doi.org/10.1093/geronb/57.3.S158
Barker JC, King D. Taking care of my parents' friends: non-kin guardians and their older female wards. J Elder Abuse Negl 2001;3(1):45-69. https://doi.org/10.1300/J084v13n01_03

Boggs JM, Dickman J, King DK, Wright LA, Helander K, Retrum JH, Gozansky WS. Perspectives of LGBTQ older adults on aging in place: a qualitative investigation. Journal of Homosexuality 2017;64(11):1539-60. https://dx.doi.org/10.1080\% 2F00918369.2016.1247539 
Cramm JM, Nieboer AO. Neighborhood attributes security and solidarity promote the well-being of community-dwelling older people in the Netherlands. Geriatr Gerontol Int 2014;14(3):681-8. https://doi.org/10.1111/ggi.12133

Day R. Local urban environments and the wellbeing of older people. Scottish Centre for Research on Social Justice. University of Glasgow, University of Birmingham, 2008. Internet: https://www. gla.ac.uk/media/Media_70702_smxx.pdf (viitattu 12.5.2021).

Deindl C, Brandt M. Support networks of childless older people: informal and formal support in $\mathrm{Eu}-$ rope. Ageing Soc 2017;37(8):1543-67. https://doi.org/10.1017/S0144686X16000416

Dunér A, Nordström M. The roles and functions of the informal support networks of older people who receive formal support: a Swedish qualitative study. Ageing Soc 2007;27(1):67-85. https://doi.org/10.1017/S0144686X06005344

Eronen AK. Hiljaista turvallisuutta? Tutkielma sukupolvien välisestä vuorovaikutuksesta Sukupolvienkorttelissa. Sosiologian pro gradu -tutkielma. Valtiotieteellinen tiedekunta, Helsingin yliopisto, 2019.

Fuller-Thomson E, Minkler M, Driver D. A profile of grandparents raising grandchildren in the United States. Gerontologist 1997;37(3):406-11. https://doi.org/10.1093/geront/37.3.406

Gardner PJ. Natural neighborhood networks - important social networks in the lives of older adults aging in place. J Aging Stud 2011;25(3):263-71. https://doi.org/10.1016/j.jaging.2011.03.007

Greenfield EA. Support from neighbors and aging in place: can NORC programs make a difference? Gerontologist 2016;56(4):651-9. https://doi.org/10.1093/geront/gnu162

Grime JC. Older people's experiences of getting help from neighbors. Work Older People 2018;22(3):178-86. https://doi.org/10.1108/WWOP-03-2018-0010

Hand C, Laliberte Rudman D, Huot S, Pack R, Gilliland J. Enacting agency: exploring how older adults shape their neighbourhoods. Ageing Soc 2018;40(3):565-83. https://doi.org/10.1017/S0144686X18001150

Heikkinen E, Marin M, toim. Vanhuuden voimavarat. Helsinki: Tammi, 2002.

Hirvonen J. Suomalaisen naapuruuden piirteitä asukaskyselyn valossa. Aalto University Series
Science + Technology 4/2013.

https://aaltodoc.aalto.fi/handle/123456789/8964

Jaakkola E. Yhteisöllisyys syrjäisellä maaseudulla asuvien ikääntyneiden arjessa. Acta electronica Universitatis Lapponiensis 175. Lapin yliopisto, 2015.

Jolanki O, Vilkko A. The meaning of a "sense of community" in a Finnish senior co-housing community. J Hous Elderly 2015;29(1-2):111-25. https://doi.org/10.1080/02763893.2015.989767

Jolanki O, Leinonen E, Rajaniemi J, Rappe E, Räsänen T, Teittinen O, Topo P. Asumisen yhteisöllisyys ja hyvä vanhuus. Valtioneuvoston selvitys- ja tutkimustoimikunnan julkaisusarja 47/2017. https://julkaisut.valtioneuvosto.fi/handle/10024/79913

Kafková M P. Older people as care givers and their roles in family in the era of active ageing: the case of the Czech Republic. Studia Socjologiczne 2015;2(217):49-73.

Kangassalo R, Teeri S. Yksinäisyys kotona asuvien iäkkäiden elämässä. Gerontologia 2017;31(4):27890.

Kariniemi K, Siira H, Kyngäs H, Kaakinen P. ”Vanhakin on ihminen": ikääntyneiden kokemuksia vahvuuksistaan, voimavaroistaan ja kotihoidosta. Gerontologia 2020;34(1):24-41.

Keating N, Otfinowski P, Wenger C, Fast J, Derksen L. Understanding the caring capacity of informal networks of frail seniors: a case for care networks. Ageing Soc 2003;23(1):115-27. https://doi.org/10.1017/S0144686X02008954

Kouvo A, Haverinen R. Dealing with disturbances: interventions and adaptation in Finnish neighbourhoods. Urban Stud 2017;54(16):3755-71. https://doi.org/10.1177\%2F0042098016684732

Kuisma E. Yli 90-vuotiaiden vanhusten sosiaaliset suhteet mielenterveyttä tukemassa. Pro gradu -tutkielma. Terveystieteiden yksikkö, hoitotiede, Tampereen yliopisto, 2017.

Lager D, Van Hoven B, Huigen PPP. Understanding older adults' social capital in place: obstacles to and opportunities for social contacts in the neighbourhood. Geoforum 2015;59:87-97. https://doi.org/10.1016/j.geoforum.2014.12.009

Lapierre TA, Keating N. Characteristics and contributions of non-kin carers of older people: a closer look at friends and neighbours. Ageing Soc 2013;33(8):1442-68. https://doi.org/10.1017/S0144686X12000736 
Litwin H, Shiovitz-Ezra S. Network type and mortality risk in later life. Gerontologist 2006;46(6): 735-43.https://doi.org/10.1093/geront/46.6.735

Narushima M. A gaggle of raging grannies: the empowerment of older Canadian women through social activism. Int J Lifelong Educ 2004;23(1):23-42.

https://doi.org/10.1080/0260137032000172042

Narushima M.'Payback time': community volunteering among older adults as a transformative mechanism. Ageing Soc 2005;25(4):567-84. https://doi.org/10.1017/S0144686X05003661

Nocon A, Pearson M. The roles of friends and neighbors in providing support for older people. Ageing Soc 2000;20(3):341-367. https://doi.org/10.1017/S0144686X99007771

Nurmela T. Sosiaalisen osallisuuden ilmeneminen ikääntyneiden arjessa. Sosiaalityön pro gradu -tutkielma. Yhteiskuntatieteiden tiedekunta, Lapin yliopisto, 2012.

O'Dare CE, Timonen V, Conlon C. Intergenerational friendships of older adults: why do we know so little about them? Ageing Soc 2019a;39(1):1-16. https://doi.org/10.1017/S0144686X17000800

O'Dare CE, Timonen V, Conlon C. Escaping 'the old fogey': doing age through intergenerational friendship. J Aging Stud 2019b;48:67-75. https://doi.org/10.1016/j.jaging.2019.01.004

Palkeinen H. Yksinäisyys ja vanhuus - erottamaton parivaljakko? Janus 2007;15(2):104-17.

Pedersen J. The raging grannies: activist grandmothering for peace. Journal of the Motherhood Initiative 2010;1(1):64-74.

Pietilä I. Työmiehen vanheneva ruumis ja miesten sosiaaliset järjestykset. Teoksessa Ojala H, Pietilä I, toim. Miehistä puhetta: miehet, ikääntyminen ja vanhenemisen kulttuuriset mallit. Tampere: Tampere University Press, 2013:197-223.

Saarenheimo M, toim. Neljän polven treffit: ikäpolvitoiminnan opas. Vanhustyön keskusliitto, 2013. https://vtkl.fi/wp-content/uploads/2019/06/ Neljan_Polven_Treffit_Ikapolvitoiminnan_ Opas.pdf

Sarvimäki A. Ikäihmisten elämänlaatu hyvänä arkena. Teoksessa Rajaniemi J, Heimonen S, Sarvimäki A, Tiihonen A, toim. Ikääntyneiden arki: näkökulmia ikäihmisten arjen kysymyksiin. Oraita 2/2017. Ikäinstituutti, 2017:50-62. Internet: https://www.ikainstituutti.fi/content/ uploads/2019/11/Oraita-2-2007-PDF.pdf (viitattu 12.5.2021).
Schwanen T, Banister D, Bowling A. Independence and mobility in later life. Geoforum 2012;43(6):1313-22. https://doi.org/10.1016/j.geoforum.2012.04.001

Seifer A, König R. Help from and help to neighbors among older adults in Europe. Front Sociol 2019;4:e46.

https://doi.org/10.3389/fsoc.2019.00046

Seppänen M, Haapola I, Puolakka K, Tiilikainen E. Takaisin Liipolaan - lähiö fyysisenä ja sosiaalisena asuinympäristönä. Ympäristöministeriön raportteja 14/2012.

Shaw BA. Anticipated support from neighbors and physical functioning during later life. Res Aging 2005;27(5):503-25.

https://doi.org/10.1177\%2F0164027505277884

Suomi A, Hakonen S, toim. Kuluerästä voimavaraksi: sosiokulttuurinen puheenvuoro ikääntymiskysymyksiin. Jyväskylä: PS-Kustannus, 2008.

SVT. Suomen virallinen tilasto. Asunnot ja asuinolot. 2019 Helsinki: Tilastokeskus. Internet: https:// www.stat.fi/til/asas/2019/asas_2019_2020-0520_tie_001_fi.html (viitattu 12.5.2021).

Thomas WH, Blanchard JL. Moving beyond place: aging in community. Generations 2009;33(2): $12-7$.

Thornton JE. Myths of aging or ageist stereotypes. Educ Gerontol 2002;28(4):301-12. https://doi.org/10.1080/036012702753590415

Tilastokeskus. Yhä useampi ikäihminen asuu kotona - yli puolet pientaloissa. 2019. Internet: https://tilastokeskus.fi/tietotrendit/artikkelit/2019/yha-useampi-ikaihminen-asuu-kotona-yli-puolet-pientaloissa/?listing=simple (viitattu 12.5.2021).

Topo P, Jyrkämä J. Iäkkäät kasvattamassa yhteisiä ja yksityisiä voimavaroja. Gerontologia 2020;34(4): 323-7.

Trickey R, Kelley-Gillespie N, Farley OW. A look at a community coming together to meet the needs of older adults: an evaluation of the neighbors Helping Neighbors program. J Gerontol Soc Work 2008;50(3-4):81-98. https://doi.org/10.1300/j083v50n3_07

Tuominen K, Pirhonen J. "Who would take a 90year old?" Community-dwelling nonagetarians' perceptions of social relationships. Int J Ageing Later Life 2019;13(1):111-37. https://doi.org/10.3384/ijal.1652-8670.18387

Uotila H. Vanhuus ja yksinäisyys: tutkimus iäkkäiden ihmisten yksinäisyyskokemuksista, niiden merki- 
tyksistä ja tulkinnoista. Tampere: Tampere University Press, 2011.

van Dijk HM, Cramm JM, Nieboer AP. The experiences of neighbor, volunteer and professional support-givers in supporting community dwelling older people. Health Soc Care Community 2013;21(2):150-8.

https://doi.org/10.1111/hsc.12006

Vasara P. Mahdollinen, välttämätön ja väistämätön.

Teoksessa Juhila K, Kröger T, toim. Siirtymät ja valinnat asumispolulla. SoPhi: Jyväskylän yliopisto, 2016:85-107.

https://jyx.jyu.fi/handle/123456789/50391

Vasara P. Väistämättömyyksiä ja valintoja: kertomuksia ikäihmisten asumispolulta. JYU Dissertations 212. Jyväskylän yliopisto, 2020.

https://jyx.jyu.fi/handle/123456789/68763

Vidovicová L. New roles for older people. Population Ageing 2018;11:1-6. https://doi.org/10.1007/s12062-017-9217-z

von Faber M, Bootsma-van der Wiel A, van Exel E, Gussekloo J, Lagaay AM, van Dongen E ym. Successful aging in the oldest old: who can be characterized as successfully aged? Arch Intern Med 2001;161(22):2694-700.

https://doi.org/10.1001/archinte.161.22.2694

Vuorimies M. Kotihoidossa olevien vanhusten sosiaaliset suhteet ja osallistuminen kodin ulko- puoliseen toimintaan. Opinnäytetyö. Hoitotyön koulutusohjelma, Vaasan ammattikorkeakoulu, 2012.

Vuorinen L. Ikääntyminen maalaiskylässä. Sosiaalipolitiikan väitöskirja. Yhteiskuntapolitiikan laitos, Helsingin yliopisto, 2009.

Wenger CG. The special role of friends and neighbors. J Aging Stud 1990;4(2):149-69.

https://doi.org/10.1016/0890-

4065(90)90012-W

Wenger CG, Dykstra PA, Melkas T, Knipscheer KCPM. Social embeddedness and late-life parenthood. J Fam Issues 2007;28(11):1419-56. https://doi.org/10.1177\%2F0192513X07303895

Wiles JL, Jayasinha R. Care for place: the contributions older people make to their communities. J Aging Stud 2013;27(2):93-101. https://doi.org/10.1016/j.jaging.2012.12.001

Ziegler F. "You have to engage with life, or life will go away": an intersectional life course analysis of older women's social participation in a disadvantaged urban area. Geoforum 2012;43(6):1296305.

https://doi.org/10.1016/j.geoforum.2012.03.013 Äyräväinen I, Piirainen A, Lintunen T, Rantanen T. Vapaaehtoistyöntekijöiden kokemuksia vastavuoroisuudesta ikääntyneiden ihmisten vapaaehtoistyössä. Gerontologia 2019;33(1):3-18. 